\title{
Assessment of Trace Metal Levels In Commonly Edible Vegetables From Selected Markets In Lagos State, Nigeria
}

\author{
A.A ADU ${ }^{1}$, O.J ADERINOLA ${ }^{2 *}$ and V. KUSEMIJU² \\ 'Department of Botany, Faculty of Science Lagos State University, Ojo, Lagos Nigeria. \\ "Department of Zoology and Environmental Biology, Faculty of Science, \\ Lagos State University, Ojo Lagos Nigeria.
}

http://dx.doi.org/10.12944/CWE.9.3.28

(Received: August 09, 2014; Accepted: October 29, 2014)

\begin{abstract}
Consumption of food contaminated with heavy metals is a major source of health problems for man and animals. Three commonly edible Leafy vegetables (Amaranthus hybridus, Celosia argentea ,Cochorus olitoris) from Agboju and Iba markets, Lagos Nigeria were sampled, identified, digested and analyzed with the aid of Atomic Absorption Spectrophotometer (AAS) as directed by APHA (American Public Health Association) to determine heavy metals concentration in them with the aim of ascertaining their edibility for human consumption. The mean concentration for each heavy metal in the samples gotten from each market were calculated, the comparison of these data was done amongst the two markets, and compared with the permissible levels set by the FAO and WHO. The results showed that the levels of Lead, Cadmium, Copper, Zinc, Iron, Nickel, Selenium and Chromium present in the vegetable concentrated in the following order $\mathrm{Fe}>\mathrm{Pb}>\mathrm{Zn}>\mathrm{Cd}>\mathrm{Ni}>\mathrm{Cu}>\mathrm{Cr}>\mathrm{Se}$. With regards to vegetables in questions, analysis of variance showed that some vegetables accumulated metals more than each other and as such indicated that metals like copper, cadmium, selenium, iron and zinc are significant at $\mathrm{P}<0.05$ ) while others were not. Whereas with regards to locations, Iron, cadmium and lead were significant at $P<(0.05)$ while other metals were not significant $P>0.05)$. With significant values of lead, cadmium and nickel, recorded in both Amaranthus hybridus and Celosia argentea vegetables, vegetables consumers must be weary of vegetables to buy and the market that is save to buy from, especially markets located very close to highways or close to major busy roads .
\end{abstract}

Key words: Trace metals, Leafy vegetables Agboju market, Lyana-Iba markets, Amaranthus hybridus, Celosia argentea, Cochorus olitoris.

\section{INTRODUCTION}

Environmental pollution nowadays is a big concern. Anthropogenic activities like mining, industry and agriculture have altered the environment significantly throughout the Earth. Trace element have great significance due to their tendency to accumulate in the vital human organs over prolong period of time. Injury to vegetation caused by trace metal has been well recognized because of many botanical and chemical investigations during past 100 years. More than 60 elements in various parts of human body have been detected (Schwarz 1977). Trace quantities of certain heavy elements, such as chromium, Nickel, copper; Iron and zinc are essential micronutrients for higher animals and for plant growth. Lead $(\mathrm{Pb})$, cadmium $(\mathrm{Cd})$, and nickel (Ni) are significant environmental pollutants that are capable of interfering in the physiological process of aquatic organisms. Anthropogenic activities, such as agriculture, industry and urban life increase the $\mathrm{Pb}, \mathrm{Cd}$, and $\mathrm{Ni}$ contents of soils and waters and, therefore, have an effect on the metal contents of vegetables (Naser, 2009)

Leafy vegetables are widely used for culinary purposes. They are used to increase the quality of soups (leafy vegetables) and also for their dietary purposes (Sobukola et al., 2007). They are made up of chiefly cellulose, hemi-cellulose and pectin substances that give them their texture and firmness (Sobukola et. al, 2007). 
Vegetables are well thought-out as "Protective supplementary food". They contain large quantities of minerals, vitamins, carbohydrates, essential amino acid and dietary fibers, which are required for normal functioning of human metabolic processes. They are also important to neutralize the acid produced during digestion, besides being useful "roughage" according to food experts. It is therefore necessary to assess the level of trace elements concentration in different varieties of vegetables (Elbagermi, 2012). Trace elements along with other pollutants are discharged into the environment through industrial activity, automobile exhaust, heavy-duty electric power generators, refuse burning and of use pesticides in agriculture etc. Man, animals and plants take up these metals from the environment through air, water and food.

The role of trace elements in body metabolism is of prime importance. Their deficiency causes diseases, whereas their presence in excess may result in toxicity to human life. Vegetables take up metals by absorbing them from contaminated soils, as well as from deposits on different parts of the vegetables exposed to the air from polluted environments (Sobukola et al 2007). Vegetable plants growing on heavy metal contaminated medium can accumulate high concentrations of trace elements to cause serious health risk to consumers (Ahmad et al, 2009).

Based on persistent nature and cumulative behavior as well as the probability of potential toxicity effects of heavy metals as a result of consumption of leafy vegetables and fruits, there is need to test and analyze these food items to ensure that the levels of these trace elements meet the agreed international requirements. This is particularly important for farm products from this part of the world where only limited data on heavy metal contents of such highly consumed agricultural materials are available.

This study therefore, presents data on the levels of Iron (Fe), Copper (Cu), Lead (Pb), Zinc $(\mathrm{Zn})$, Selenium (Se), Nickel (Ni) and Cadmium (Cd) in three selected varieties of leafy vegetables, ; Celosia argentea, Amaranthus hybridus, Cochorus olitoris belonging to three (2) different families abundantly consumed by local population. Family Amaranthaceae (Amaranthus caudatus and
Celosia argentea) and Family Malvaceae (Cochorus olitorius)

The samples were gotten at two different markets (Agboju and Iba) in West Africa's most popular mega city, Lagos, Nigeria.

\section{MATERIALS AND METHOD}

\section{Study area}

This study was conducted in southwest city of Lagos Nigeria. The area has a bimodal rainfall pattern with peaks in June and September and is the commercial capital of Nigeria. It is characterized by the heaviest traffic on major highways along where the commercial vegetable cropping takes place. The soils in this area are from sedimentary rock formation.

\section{Collection of samples}

Three Plants sample were collected from two different markets (Agboju and Iba). These are popular markets which supply lots of markets in the state and are exposed to various anthropogenic activities. Samples are Celosia argentea( Cockscomb, Soko in Yoruba), Cochorus olitorus(Jute, Ewedu in Yoruba), Amaranthus hybridus ( Green amaranth or pigweed, inine in Igbo, teteabalaye in yoruba)

\section{Digestion process}

10 grams of each plant sample was weighed into a quartz beaker with $10 \mathrm{mls}$ of $\mathrm{HNO}_{3}$ added and gently heated on a hot plate. Heating was then continued until the brown fumes turn to white. The beaker was brought down to cool to room temperature. The mixture was rinsed with $20 \mathrm{mls}$ of deionized water and filtered into a standard $25 \mathrm{mls}$ volumetric flask and made up to mark in readiness for atomic absorption spectrophotometry AAS using whatman filter papers.

\section{RESULTS}

The results of analysis of bioaccumulation of various heavy metals considered in the samples are presented in presented in Table 1.and 2. In this experiment, eight heavy metals were considered in three selected varieties of leafy vegetables, namely Celosia argentea, (Soko) Amaranthus hybridus, (Green) and Cochorus olitoris (Ewedu) belonging 
to three (2) different families abundantly consumed by local population. The samples were gotten at two different markets (Agboju and Iba) in West Africa's most popular mega city, Lagos, Nigeria.

The results showed that cadmium, nickel iron and lead were highly bioaccumulated by vegetables bought from Agboju markets (Table 1). The values were cadmium (0.035 \pm .002 Amaranthus hybridus), lead (0.123 \pm .001 Celosia argentea), nickel (0.023 \pm 003 Celosia argentea) and iron

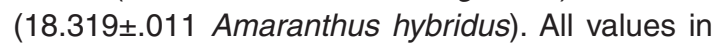
$\mathrm{Mg} / \mathrm{Kg}$ respectively. It could also be observed that most the metals concentrated mostly in Green and Soko vegetables i.e. Amaranthus hybridus, and Celosia argentea. The values were lower in other vegetables which could mean that different vegetables bioaccumulated chemicals differently.
On the other hand, vegetables such as Green and Soko i. e Amaranthus hybridus and Celosia argentea bought from Iba market bioaccumulated Copper (0.013 \pm .005 Amaranthus hybridus), selenium (0.006 \pm .001 Amaranthus hybridus) and zinc $(0.083 \pm 0.002$, Celosia argentea), chromium (0.052 \pm .013 Celosia argentea). Tables 1 , figure 1-2

With regards to vegetables in questions, analysis of variance showed that some vegetables accumulated metals more than each other and as such indicated that metals like copper, cadmium, selenium, iron and zinc are significant at $\mathrm{P}<0.05$ while others were not.

Whereas with regards to locations, Iron, cadmium and lead were significant at $\mathrm{P}<0.05$ while other metals were not significant $\mathrm{P}>0.05$

Table. 1: Concentration of metals in the three vegetables namely Amaranthus hybridus, (Green), Cochorus olitoris) (Ewedu) and Celosia argentea (Soko) collected at Agboju and Iba market, Lagos.

\begin{tabular}{|c|c|c|c|c|c|c|}
\hline \multirow[b]{3}{*}{ Location } & \multicolumn{6}{|c|}{ Vegetable types } \\
\hline & \multicolumn{2}{|c|}{ Green } & \multicolumn{2}{|c|}{ Ewedu } & \multicolumn{2}{|c|}{ Soko } \\
\hline & Mean & Std. Dev & Mean & Std. Dev & Mean & Std. Dev \\
\hline \multicolumn{7}{|l|}{ Agboju Market } \\
\hline Copper (mg/kg) & 0.009 & .001 & 0.005 & .004 & 0.007 & .002 \\
\hline Cadmium & 0.035 & .002 & 0.023 & .002 & 0.019 & .001 \\
\hline Nickel (mg/kg) & 0.009 & .001 & 0.005 & .001 & 0.023 & .003 \\
\hline Selenium (mg/kg) & 0.004 & .001 & 0.001 & .001 & 0.004 & .001 \\
\hline Iron (mg/kg) & 18.319 & .011 & 12.145 & .001 & 14.286 & .003 \\
\hline Lead (mg/kg) & 0.095 & .004 & 0.015 & .001 & 0.123 & .001 \\
\hline Zinc (mg/kg) & 0.034 & .002 & 0.066 & .002 & 0.042 & .002 \\
\hline Chromium (mg/kg) & 0.005 & .001 & 0.004 & .002 & 0.004 & .001 \\
\hline \multicolumn{7}{|l|}{ Iba Market } \\
\hline Copper (mg/kg) & 0.013 & .005 & 0.004 & .001 & 0.009 & .001 \\
\hline Cadmium & 0.025 & .001 & 0.014 & .001 & 0.013 & .001 \\
\hline Nickel (mg/kg) & 0.010 & .001 & 0.021 & .002 & 0.007 & .001 \\
\hline Selenium (mg/kg) & 0.006 & .001 & 0.002 & .001 & 0.003 & .002 \\
\hline Iron (mg/kg) & 14.214 & 4.471 & 3.123 & .002 & 6.214 & .002 \\
\hline Lead (mg/kg) & 0.046 & .001 & 0.025 & .001 & 0.008 & .001 \\
\hline Zinc (mg/kg) & 0.050 & .002 & 0.054 & .001 & 0.083 & .002 \\
\hline Chromium (mg/kg) & 0.007 & .002 & 0.004 & .001 & 0.052 & .013 \\
\hline
\end{tabular}

With regards to metals in vegetables, Copper, cadmium, selenium, iron and chromium were Significant @ $\mathrm{P}<0.05$. 


\section{DISCUSSION}

The trace metal like $\mathrm{Fe}, \mathrm{Cu}$, and zinc are considered as essential elements for normal life processes, whereas the function of $\mathrm{Zn}$ in the human body is well defined. $\mathrm{Cr}, \mathrm{Cd}, \mathrm{Pb}, \mathrm{Ni}$ and $\mathrm{Se}$ are toxic trace metal and its function in the animal and human body is comprehensively documented (Gullfraz et al., 2001). The results show that the vegetables studied appears to be rich in iron, copper and zinc (Table 1) and these vegetables may thus compensate for the deficient intake of metal through other diet.

In vegetables bought from Iba market, viz Amaranthus hybridus, Celosia argentea and Cochorus olitoris the result showed that Amaranthus hybridus bioaccumulated high concentration of copper and selenium while Celosia argentea bioconcentrated high level of zinc and chromium.
Analysis of variance equally showed that metals like copper, cadmium, selenium, iron and chromium were significantly bioaccumulated at $(\mathrm{P}<0.05)$ with regards to vegetables. This indicated that consumers need to be weary of vegetables they should buy as consumptions of vegetables with significant levels of such metals incorporated in them could be dangerous to health.

On the other hand, with regards to location, especially a market like Agboju, analysis of variance showed that cadmium, iron and lead were significant $(\mathrm{P}<0.05)$. This means that Agboju market is a dumping site for most vegetables probably bought from road side farmers and that buyers of such vegetables need to visit other market for their vegetables product to avoid been poisoned by vegetables been grown with chemicals or that are very close to the major highways in Lagos Nigeria.

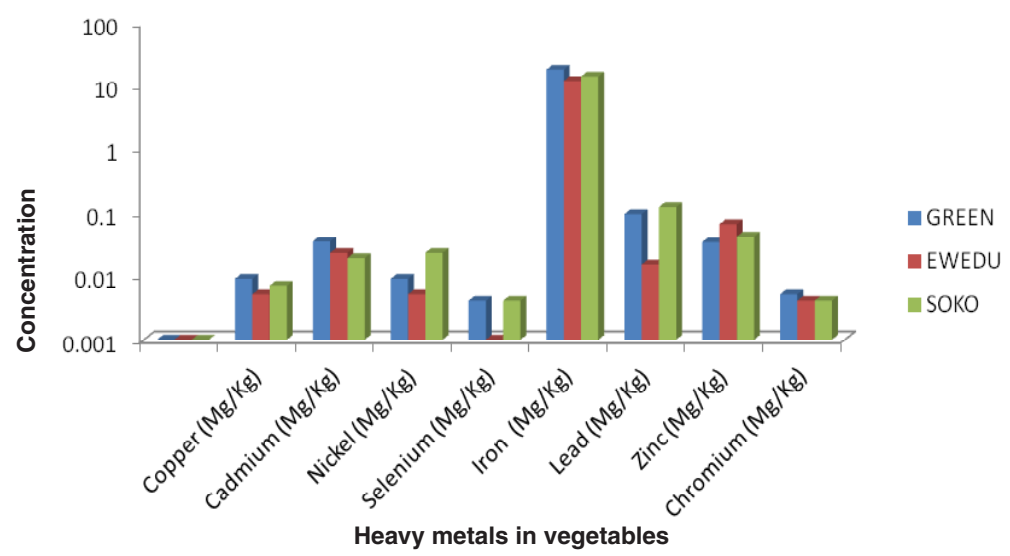

Fig. 1: Concentration of heavy metals in the three vegetables from Agboju Market

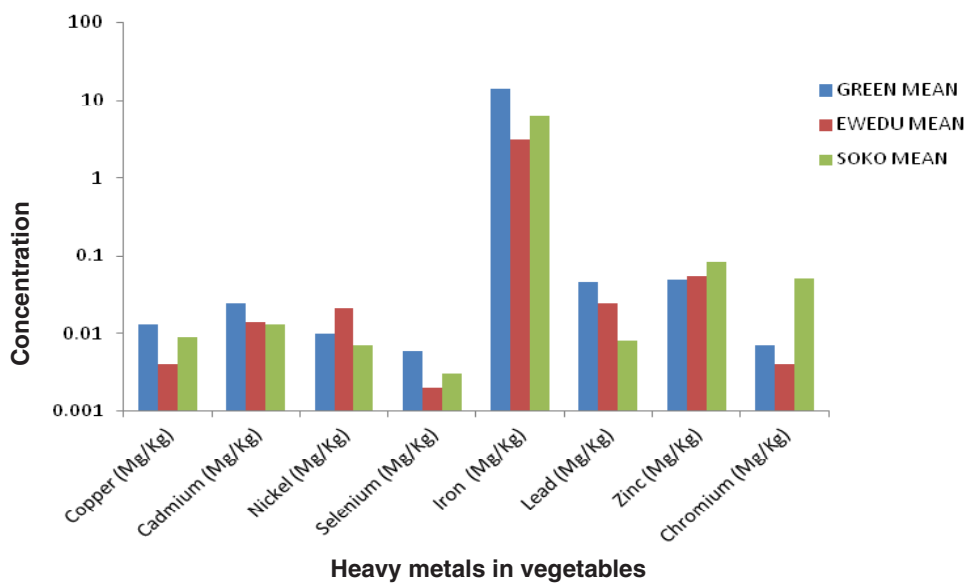

Fig. 2: Concentration of heavy metals in the three vegetables from lba Market 
This indicated that the values recorded could be dangerous to the health of the consumers if vital steps are not taken by the appropriate agencies to look into the source of these heavy metals in the animal's food chain.

Furthermore, with regards to Iba market, results showed that vegetables green bioaccumulated high levels of copper $(0.013 \pm 0.005)$, selenium $(0.006 \pm 0.001)$ and in Celosia argentea $(0.083 \pm 0.002)$ and chromium $(0.052 \pm 0.013) \mathrm{in} \mathrm{Mg} /$ $\mathrm{Kg}$ respectively.

During this study, the concentration of zinc was found high in the vegetable sample of Celosia argentea (Iba market with value of, $0.08 \mathrm{mg} / \mathrm{g}$ ) while low concentration of zinc was observed in sample from Celosia argentea (Agboju market, 0.047 $\mathrm{mg} / \mathrm{g}$ ). The content of zinc in this report also shows similarity with the their result of Doherty (2007), whose result ranges from 0.04 to $0.77 \mathrm{mg} / \mathrm{g}$ which is also within safe limit with respect to FAO/WHOCodex alimentarius commission, 2001 (99.40mg/ $\mathrm{kg}$ ). Excessive intake of Zinc can have long term effects whereas the deficiency syndrome manifests itself by retardation of growth, anorexia, lesions of skin and appendages, impaired development and function of reproductive organs. In view of this the estimated concentrations of metals in vegetables under investigation do not cause health hazards for consumers.

Concentration of $\mathrm{Cu}$ recorded in these vegetables was $0.013 \mathrm{mg} / \mathrm{Kg}$. A daily dietary intake of 2 to $3 \mathrm{mg}$ of copper is recommended for human adults (Dara, 1993). The results show that the vegetables studied appears to be rich in copper as these vegetables may thus compensate for the deficient intake of metal through other diet. It is necessary for normal biological activities of amino-oxides and tyrosinase enzymes. Tyrosinase is required for the catalytic conversion of tyrosine to melanin, the vital pigment located beneath the skin, which protects the skin from dangerous radiation.

$\mathrm{Pb}$ is a serious cumulative body poison, which enters into the body system through air, water and food and cannot be removed by washing fruits and vegetables (Chove et al., 2003). Lead has been shown to have toxic impact on a variety of metabolic processes essential to plant growth and development, including photosynthesis, transpiration, DNA synthesis, and mitotic activity (Pehlivana et al, 2008). The Green and Soko samples had Pb content that was higher than the FAO standard of $0.3 \mathrm{mg} / \mathrm{kg}$. The results showed $\mathrm{Pb}$ contents in Soko at Agboju and $\mathrm{lba}$ at $0.122 \mathrm{mg} / \mathrm{kg}$ to $0.008 \mathrm{mg} / \mathrm{kg}$. This called our attention because on a personal communication with the sellers of these vegetables, revealed that they both bought the vegetables from the same location; a field close to LASU gate. The question is how come the high difference? Taking a closer look at the location of these two markets, although both close to the road, that of Agboju was a much busier route with a lot of smoke coming from exhaust of cars. The high levels of $\mathrm{Pb}$ in some plants may probably be attributed to pollutants in irrigation water, farm soil or due to pollution from the highways traffic (Anhwange et al., 2004). It can be stated that the site of growth noticeably influences the heavy metal uptake by vegetables.

Generally, lead contaminations occur in vegetables grown on contaminated soil. Lead poisoning is a global reality, and fortunately is not a very common clinical diagnosis yet in Nigeria except for few occupational exposures (Adewuyi et al, 2006). Sources of lead include metal smelting, pigments, lead battery manufacturing and lead contaminated petrol. In soil Lead tightly binds itself to organic soil particles which may decrease the mobility of lead in most soils and may reduce uptake by plants (Kudirat et al, 2011). It has been suggested that the mobility of lead and copper is greater in sandy soils, which tend to lack organic matter, than in organic soils. This however doesn't imply that the results for all vegetables coming from Agboju were higher than that of Iba.

Among these metals, zinc is the least toxic and an essential element in human diet as it requires maintaining the functioning of the immune system. Zinc has been well known to be an important trace element as a cofactor for insulin. (Abdu et al). Zinc deficiency in the diet may be highly detrimental to human health than too much zinc in the diet. It may be due to inadequate dietary intake, impaired absorption, excessive excretion or inherited defects in zinc metabolism (Pehlivana, 2008). The recommended dietary allowance for zinc is $15 \mathrm{mg} /$ 
day for men and $12 \mathrm{mg} /$ day for women (Lawrence et al., 1993) but high concentration of zinc in vegetables may cause vomiting, renal damage, cramps . During this study, the concentration of zinc was found high in the sample from Soko (Agboju, $0.122 \mathrm{mg} / \mathrm{g}$ ) while low concentration of zinc was observed in sample from Soko (lba, $0.008 \mathrm{mg} / \mathrm{g})$. The content of zinc in this report also shows similarity the their result of V.F Doherty, whose result ranges from 0.04 to 0.77 $\mathrm{mg} / \mathrm{g}$ which is also within safe limit (Doherty, 2009)

It was also noticed that the Cd level was higher in all plants gotten from Agboju than that gotten from Iba. Since the major sources of cadmium are fuel burning, batteries and tire wear, there may be difference in cadmium level due to difference in the population of residents in these localities. The rate at which vehicles (that brings about tire wear, fuel burning, batteries discharge) are utilized differs.

$\mathrm{FAO} / \mathrm{WHO}$, the safe limit for $\mathrm{Cd}$ consumption in vegetables is $0.2 \mathrm{mg} / \mathrm{kg}$ - Kudirat et al 2007, Cadmium is toxic to human even at low concentrations. Cadmium is used in batteries, pigments, fertilizers, detergents and it is also present in refined petroleum products. It is reported to cause osteomalacia (Hashmi, 2007). It badly affects the cardio vascular system and kidney functioning. The mean concentration of cadmium was approximately similar in green from Agboju $(0.032 \mathrm{mg} / \mathrm{kg})$ and Ewedu, $(0.022 \mathrm{mg} / \mathrm{kg})$ although it was highest in green, of Agboju.market.

Cadmium in particular is an Environmental Protection Agency (EPA) regulated heavy metal that is used as anticorrosion and decorative coatings on metal alloys. Cadmium enters waterways through industrial discharges and galvanized pipe breakdown. It is a non-essential metal to living organisms and can become toxic by displacing zinc. Low exposures may result in kidney damage (Ahmad, 2007). In addition, epidemiological studies have revealed that cadmium may be a contributing factor in some forms of cancer in humans (Sobukola, 2010)

There were significant differences in the $\mathrm{Cr}, \mathrm{Cu}$, and $\mathrm{Ni}$ concentrations of the different vegetable species (Soko, Green, and Ewedu) in the two different locations. In all three vegetables regardless of locations, a similar trend in metal contents was observed i.e., $\mathrm{Cr}<\mathrm{Ni}<\mathrm{Fe}$. Nickel content (dry wt. basis) was found to be the highest in Soko (agboju) with a range of $0.021 \mathrm{mg} / \mathrm{kg}$. Selenium is an essential trace element. It is an integral part of enzymes. Selenium has a variety of functions. The main one is its role as an anti-oxidant in the enzyme Selenium-glutathione-peroxidase. Selenium also seems to stimulate antibody formation in response to vaccines. It also may provide protection from the toxic effects of heavy metals and other substances. It may assist in the synthesis of protein, in growth and development and in fertility, especially in men. Selenium has been shown to improve the production of sperm and sperm mobility. Edmark (2003).

Selenium recorded an all-time low in the results from both markets. It went as low as $0.001 \mathrm{mg} / \mathrm{kg}$ in Soko,( Iba), to $0.006 \mathrm{mg} / \mathrm{kg}$ in Green (lba). Copper is an essential enzymatic element. Such concentrations level of copper are necessary for normal biological activities of amino oxides and tyrosinase enzyme. Tyrosinase is the enzyme that is required for catalytic conversion of tyrosine to melanin, which is a vital pigment located beneath the skin, and thus protects the skin from dangerous radiations (Hashmi, et al., 2007). Apart from its function as a biocatalyst, $\mathrm{Cu}$ is necessary for body pigmentation, for the maintenance of a healthy central nervous system, and for the prevention of anemia, and it is interrelated with the function of $\mathrm{Zn}$ and $\mathrm{Fe}$ in the body. Copper normally finds its way into drinking water from copper pipes, as well as additives designed to control algal growth. Concentration of copper in our plant samples ranged from 0.003 to $0.014 \mathrm{mg} / \mathrm{kg}$ whereas the daily dietary intake of 2-3 $\mathrm{mg}$ copper is recommended for human adults.

It is noticed that the amount of Iron available in all the collected vegetables at Agboju were higher than that of the Iba market samples. This trend was also noticed with Nickel.

Nickel regulates the mineral metabolism, enzyme activity and several other metabolic processes in plants. It is used as a fungicide but it is well toxic to the germination of some seeds. It causes mitotic disturbances in root tips of some plants. High concentrations of nickel cause severe chlorosis and necrosis in plants and a host of other 
growth abnormalities and anatomical changes (Abdu, 2003).Generally Nickel and its salts do not affect the human body but in some cases it has been recorded to cause allergic problems as it comes in contact with moist skin. It also affects adversely the lungs and nasal cavities (Pehlivana, 2008).

According to the results, concentration of Nickel ranged from 0.004 in Ewedu, Agboju to 0.021 in Soko, Agboju. Major sources of Nickel that bring it into the atmosphere involve Iron, steel and cement production and Fuel combustion to produce heat and electricity. Thus nickel levels are below the recommended daily dietary intake of nickel which is about $0.025 \mathrm{mg}$ per day.

It is reported that about $60 \%$ of the world population is iron (Fe) deficient. (Anhwange, 2008) Fe is needed in the RBC's formation and hemoglobin. Red blood cells life span is about 120 days. Fe is also a necessary metal and is core component of the red blood cells, its deficiency can cause anemia and it can also show some psychological symptoms as reduced attentiveness and loss of concentration. (Adewuyi et al, 2002) The concentration of iron was the highest of all the metals sampled, It attained the highest in Green, Agboju (18.300mg/kg), and lowest at Ewedu, Iba (3.122 mg/kg). The result also showed a higher amount of $\mathrm{Fe}$ in all the samples gotten from Agboju market than that from Iba.

Chromium is one of the known toxic pollutants in the world. At an elevated concentration it is toxic for both plant and animals. The problems that are associated with chromium involve skin rashes, stomach ulcer, kidney, liver damages, lungs cancer and ultimate death (Kirmani et al, 2011). All of our plant samples bear almost the same concentration level of chromium and it fall into the range of 0.001 to $0.007 \mathrm{mg} / \mathrm{kg}$. Major sources of Chromium in atmosphere involve Iron, steel and cement production and fuel combustion to produce heat and electricity. The table also showed that Ewedu from both Agboju and iyanaoba, in all instances but one, had the lowest concentration of trace metals from the three. Careful observation on the Ewedu leaf showed a more glabrous surface than Green and Soko which had more hairs on the leaves. What this means is that the Ewedu leaf has more tendency to repel water and smoke than the other vegetables.
Soko for instance has a smooth texture with hairs and this can harbor moisture on the leaf.

In Lagos state, lack of access to land make other lands including hazardous places such as road verges, banks of drainage channels and dumpsites are being converted to vegetable gardens. All setbacks along major highways are used by farmers for vegetable cultivation. Emissions from the heavy traffic on these roads contain lead $(\mathrm{Pb})$, cadmium $(\mathrm{Cd})$, zinc $(\mathrm{Zn})$, and nickel $(\mathrm{Ni})$, which are present in fuel as anti-knock agents. This has also led to contamination of air and soils on which these vegetables are planted (Kirmani, 2011). Excessive accumulations of heavy metal in agricultural land through traffic emission may results in soil contamination and elevated heavy metal uptake by crops, and thus affect food quality and safety (Doherty, 2004).

Slightly high levels of heavy metals were observed in the two experimental markets because most of the markets are located close to source of contamination which includes: tire wear, motor oil, grease, brake emissions, corrosion of galvanized parts, fuel burning, batteries etc. It may also be attributed to the soil on which the vegetables were grown. Henceforth I will recommend vegetables that are cultivated in rural or isolated areas which may be far away from roads and not contaminated.

\section{CONCLUSSION}

Although the concentrations of the metals established for the vegetables are lower than those permitted by $\mathrm{FAO} / \mathrm{WHO}$, what matters in the long run is the quantities consumed and the frequency of intake. There is a cumulative effect on sustained intake of heavy metals, as they are not easily removed from the body. The low presence of Selenium in the vegetables sampled at the time of this study cannot guarantee the safety of the vegetables always for consumption, regular monitoring should be conducted to detect increasing levels of lead and chromium in vegetables. Many rural and urban lowincome families in Nigeria consume large quantities of vegetables on a daily basis and this exposes them to the health risks associated with heavy metals ingestion. 


\section{REFERENCES}

1. Abdu, N. "Availability, transfer and balances of heavy metals in urban agriculture of West Africa". Kassel University Press Pg 47-49. (2003)

2. Anhwange, B.A, J.A. Kagbu, E.B. Agbaji and C.E. Gimba. "Trace Metal Contents Of Some Common Vegetables Grown On Irrigated Farms Along The Banks Of River Benue Within Makurdi Metropolis". Electronic Journal of Agricultural, environmental and food chemistry, 5(2):66-67. (2004)

3. Adewuyi G.O.; F.A. Dawodu; and N.N. Jibiri "Studies of the Concentration Levels of Heavy Metals in Vegetable (Amaranthuscaudatus) Grown in Dumpsites within Lagos Metropolis, Nigeria" Pacific Journal of Science and Technology, 3(2): 122-125. (2006)

4. Ahmad K; Z. Khan; M; Ashraf, E.E.Valeem; Z. A. Shah and L. R. Mcdowell. "Determination Of Forage Concentrations Of Lead, Nickel And Chromium In Relation To The Requirements Of Grazing Ruminants In The Salt Range", Pakistan. Pakistan Journal of Botany, 4 (1): 61-65. (2009)

5. Chove B.E, W. R. Ballegu and L.M. Chove. "Copper and Lead levels in two popular leafy vegetables grown around Morogoro Municipality, Tanzania". Tanzania Health Research Bulletin , 8(1):168-169. (2006)

6. Doherty V.F., Kanife U.C., Ladipo M.K., and Akinfemi A "Heavy Metal Levels In Vegetables From Selected Markets In Lagos, Nigeria". Electronic Journal of Agricultural, environmental and food chemistry, 9 (6): Pg 35-37. (2007)

7. Elbagerma, M.A., H.G.M. Edwards and A.I. Alajtal., (2012). Monitoring of heavy metal content in fruit and vegetables collected from production and market sites in the Misurata area of Libya. ISRN Anal. Chem., 10.5402/2012/827645.

8. Kudirat Ladipo Margaret and Doherty Victoria Funmilayo. "Heavy metal levels in vegetables from selected markets in Lagos,
Nigeria". African Journal of Food Science and Technology, 2(1): 018-021. (2011)

9. Hashmi S.K; Afridi M.B; Abbas K, S; R.A, Saleheen (2007) Factors Associated with Adherence to Anti-Hypertensive Treatment in Pakistan.

10. Lagos Waste Management Authority. "Data On Markets In Lagos State". Prs Data Bank. Pg 1-2(2009)

11. Lawrence, K.A., A.J. Pesce and S.C. Kazmierczak. Clinical Chemistry, 4th ed., Theory,

a. Analysis, Correlation, ISBN 0-323-01716-9, Published by Mosby Inc. USA, p. 707-721. (1993).

12. Naser H. M.; N N. C. Shil,; N. U. Mahmud; M. H. Rashid4 and K. M. Hossain. "Lead, Cadmium and Nickel Contents Of Vegetables Grown In Industrially Polluted And Non-Polluted Areas Of Bangladesh". Bangladesh J. Agril. Res. 34(4): 545-554. (2009)

13. Pehlivana, E., G.A.; Fethiye G.; Turkan A.; and M. M. Özcand. "Determination of some inorganic metals in edible vegetable oils by inductively coupled plasma atomic emission spectroscopy (ICP-AES)" Grasas Y Aceites, 53(3): 239-244, (2008)

14. Sobukola O.P, O.M. Adeniran, A. A. Odedairo and O. E. Kajihausa. "Heavy metal levels of some fruits and leafy vegetables from selected markets in Lagos, Nigeria." African Journal of Food Science, 4(2): 389 - 393. (2010)

15. Schwarz, K, Clinical Chemistry and Chemical Toxicology of Metals. (Ed.): S.S. Browred, Elsevier, Amsterdam, pp. 135. (1977).

16. Gulfraz, M., A. T. and H. Afzal. Concentration level of heavy and trace metals in the fish and relevant water from Rawal and Mangla Dam. Bio. Sci., 1(5): 414, pp. 105-109. (2001).

17. Dara, S.S. Environmental Chemistry and Pollution Control. First edition, published by $\mathrm{S}$. Chand and Company Ltd., New Delhi, India, pp. 184-205. (1993). 